Article

\title{
Optimal Allocation of Hybrid Renewable Energy System by Multi-Objective Water Cycle Algorithm
}

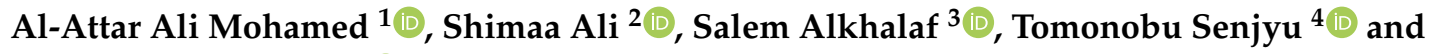 \\ Ashraf M. Hemeida $2, * \mathbb{C}$ \\ 1 Department of Electrical Engineering, Faculty of Engineering, Aswan University, Aswan 81542, Egypt; \\ attar@aswu.edu.eg \\ 2 Department of Electrical Engineering, Faculty of Energy Engineering, Aswan University, Aswan 81528, \\ Egypt; sheimaa.ali@aswu.edu.eg \\ 3 Department of Computer Science, Alrass College of Science and Arts, Qassim University, Qassim, Arrass \\ 51921, Saudi Arabia; s.alkhalaf@qu.edu.sa \\ 4 Department of Electrical and Electronics Engineering, Faculty of Engineering, University of the Ryukyus, \\ Senbaru 9030213, Japan; b985542@tec.u-ryukyu.ac.jp \\ * Correspondence: ashraf@aswu.edu.eg
}

Received: 27 September 2019; Accepted: 17 November 2019; Published: 20 November 2019

\begin{abstract}
This article offers a multi-objective framework for an optimal mix of different types of distributed energy resources (DERs) under different load models. Many renewable and non-renewable energy resources like photovoltaic system (PV), micro-turbine (MT), fuel cell (FC), and wind turbine system (WT) are incorporated in a grid-connected hybrid power system to supply energy demand. The main aim of this article is to maximize environmental, technical, and economic benefits by minimizing various objective functions such as the annual cost, power loss and greenhouse gas emission subject to different power system constraints and uncertainty of renewable energy sources. For each load model, optimum DER size and its corresponding location are calculated. To test the feasibility and validation of the multi-objective water cycle algorithm (MOWCA) is conducted on the IEEE-33 bus and IEEE-69 bus network. The concept of Pareto-optimality is applied to generate trilateral surface of non-dominant Pareto-optimal set followed by a fuzzy decision-making mechanism to obtain the final compromise solution. Multi-objective non-dominated sorting genetic (NSGA-III) algorithm is also implemented and the simulation results between two algorithms are compared with each other. The achieved simulation results evidence the better performance of MOWCA comparing with the NSGA-III algorithm and at different load models, the determined DER locations and size are always righteous for enhancement of the distribution power system performance parameters.
\end{abstract}

Keywords: Multi-objective Water Cycle Algorithm; different load models; hybrid power system; greenhouse gas emissions

\section{Introduction}

In recent years, worldwide switching towards reliable and workable hybrid renewable energy systems is mainly because of two reasons, the potential technical and economic benefits of hybrid combinations and the rapid depletion of conventional sources of energy [1]. Hybrid renewable energy (RE) systems based on photovoltaic and wind energy systems are known and implemented successfully in different locations and have a long lifetime [2]. Focusing on improving the hybrid energy sources economically and technically receives much attention from the researchers in both off-grid and on-grid. The implementation of hybrid energy sources provides better performance, and more economic than implementing PV energy system or wind energy system individually. On the other hand the hybrid 
energy sources should be designed optimally to ensure balancing the overall system arrangement [3]. Originally, the utilization of hybrid renewable energy was mainly concentrated for power generation in remote areas [4].

Multi-objective optimization (MOO) shows optimizing various objectives which are often conflicting in nature. Multi-objective optimization is much more convoluted than single-objective optimization because of the presence of multiple optimal solutions. At large, all solutions are conflicting and hence a group of non-dominated solutions is required to be found out to approximate the true Pareto front [5]. Most of the novel single-objective algorithms have been assorted with convenient mechanisms to transact with multi-objective problems (MOP) also such as Mirjalili et al offered Ant Lion Optimizer (MOALO) method in 2017 [6]. Tawhid and Savsaniin 2017 presented Multi-objective Sine Cosine Algorithm (MOSCA) [7]. A multi-objective function is optimized using hybrid an artificial immune with PSO [8]. The development of the genetic algorithm, there has been a growing interest in applying it in different applications and improving its performance by proposing new versions. For example, the multi-objective NSGA-II algorithm called non-dominated sorting genetic algorithm (NSGA-III) is proposed by Jain and Deb [9], which is more efficient to solve problems with more than two objectives. The performance measures reveal that the multi-objective water cycle algorithm (MOWCA) is better than the other algorithms such as MODA, MOGA, MOEA-D. Further, MOWCA suggests a wide range of non-dominated solutions depending on the complexity of the optimization problem [10]. Bacterial Foraging Optimization Algorithm is used to identify the optimum capacity of the DG and DSTATCOM under different load is presented in [11]. A traditional planning approach for electric distribution networks is studied under Voltage-dependent load mode considering other environmental and economic perspectives in [12].

There are many issues to be studied in the case of hybrid systems. Chauhan and Saini [13] in 2016 studied the combination of Micro Hydro Power (MHP), biogas, biomass, wind, and solar energy in order to meet the electrical and cooking demands of the study area. In 2017, Halabi et al [14] published a paper in which they had described the technical, economical, and environmental aspects of the combination of PV/diesel/battery systems using HOMER. Also, Singh and Fernandez, in 2017, studied the optimization of hybrid PV/wind/battery energy sources developed for remote regions [15]. Guangqian et al [16], in 2018, studied practical and a frugal aspect of hybrid energy sources is presented in Iran. Peng et al [17], in 2018, researched technical and economical concepts of the hybrid system based on PV/WT/battery/RO. Also, the summaries of various articles are listed in Table 1 in order to facilitate comparison with the present study.

The prime contributions of this research work are summarized as follows:

(1) We proposed a multi-objective Water Cycle Algorithm for optimal allocation of the hybrid power system model in distribution systems. Also, an NSGA-III algorithm is performed and the simulation results between two algorithms are compared with each other

(2) Studying the impact of different load models in summer day and winter day on the optimum placement of the hybrid power system model in radial distribution systems

(3) Considering the uncertainty of renewable energy sources by using Hong's $2 m+1$ PEM method.

(4) Studying the impact of the hybrid power system model to enhance the technical, economic and environmental issues of distribution systems.

(5) Reducing the power loss is considered as a technical benefit for achieving the improve system performance, reliability, and efficiency.

(6) Minimizing energy costs because of the reduction in power loss can also be translated into economic benefits by using multiple distributed energy resources (DER) placements.

(7) Minimizing the greenhouse gas emission is considered as environmental benefit.

(8) Eventuality of the aforesaid approach is conducted on the standard IEEE 33 and IEEE 69 bus power system. 
Table 1. The summaries of various articles in the literature.

\begin{tabular}{|c|c|c|c|c|c|c|c|c|c|c|c|c|c|}
\hline \multirow{2}{*}{ Ref. no. } & \multirow{2}{*}{ Solution Method } & \multicolumn{6}{|c|}{ DER Type } & \multicolumn{3}{|c|}{ Objective Function } & \multirow{2}{*}{$\begin{array}{c}\text { Multi } \\
\text { Objective }\end{array}$} & \multirow{2}{*}{$\begin{array}{l}\text { Uncertainty } \\
\text { Effect }\end{array}$} & \multirow{2}{*}{$\begin{array}{c}\text { Different } \\
\text { Load Models }\end{array}$} \\
\hline & & PV & WT & MT & FC & Bat & $\mathrm{DE}$ & $P_{\text {Loss }}$ & TC & EM & & & \\
\hline$[18]$ & $\begin{array}{c}\text { a second-order } \\
\text { cone programming } \\
\text { model }\end{array}$ & $\checkmark$ & & & & & & $\checkmark$ & & & & $\checkmark$ & \\
\hline [19] & $\begin{array}{l}\text { Cuckoo search } \\
\text { algorithm }\end{array}$ & $\checkmark$ & $\checkmark$ & & & $\checkmark$ & & & $\checkmark$ & & $\checkmark$ & & \\
\hline [20] & $\begin{array}{l}\text { The Flower } \\
\text { Pollination } \\
\text { Algorithm (FPA) }\end{array}$ & $\checkmark$ & & & $\checkmark$ & & & & $\checkmark$ & & & & \\
\hline [21] & $\begin{array}{l}\text { biogeography-based } \\
\text { optimization } \\
\text { algorithm } \\
\end{array}$ & $\checkmark$ & & & & & & $\checkmark$ & & & $\checkmark$ & & \\
\hline [22] & PSO algorithm & $\checkmark$ & & & & $\checkmark$ & $\checkmark$ & & $\checkmark$ & $\checkmark$ & & $\checkmark$ & \\
\hline [23] & $\begin{array}{c}\text { Multi-objective ant } \\
\text { lion optimizer }\end{array}$ & $\checkmark$ & $\checkmark$ & $\checkmark$ & & & & $\checkmark$ & $\checkmark$ & & & & \\
\hline [24] & $\begin{array}{l}\text { Breeder genetic } \\
\text { algorithm (BGA). }\end{array}$ & & & & & & & $\checkmark$ & & & & & $\checkmark$ \\
\hline * & $\begin{array}{l}\text { Proposed } \\
\text { algorithms }\end{array}$ & $\checkmark$ & $\checkmark$ & $\checkmark$ & $\checkmark$ & & & $\checkmark$ & $\checkmark$ & $\checkmark$ & $\checkmark$ & $\checkmark$ & $\checkmark$ \\
\hline
\end{tabular}

The organization of the remainder of the current article is as the following, Load and uncertainty modeling discusses in part II. The formulation of the mathematical problem objective functions and constraints are presented in part III. The concept of MOWCA is briefed in part IV. Part V presents the obtained results and discussion. The article's conclusion is given in the final part of part VI.

\section{Load, Uncertainty and Distributed Energy Resources Modeling}

\subsection{Load Models}

For evaluating the impact of hybrid power system model on DER planning for various load models i.e. summer day load model (SDM) and winter day load model (WDM) loads are adopted in. The real and complex power of the load is considered as constant power in the classical load flow problems, despite, the load may be nonlinear such as industrial load residential and commercial which discussed by models in [25]. The nonlinear dependent voltage load model is represented by exponential function as the following form:

$$
\begin{gathered}
\mathrm{P}_{\mathrm{i}}=\mathrm{P}_{\mathrm{oi}} \mathrm{V}_{\mathrm{i}}^{\alpha} \\
\mathrm{Q}_{\mathrm{i}}=\mathrm{Q}_{\mathrm{oi}} \mathrm{V}_{\mathrm{i}}^{\beta}
\end{gathered}
$$

In the classical power flow solution, the load is suggested to be fixed power, where $\alpha=\beta=0$. For nonlinear loads representing commercial and residential, the real and complex power components are given in Table 2 [25].

Table 2. Exponential indices of load type [25].

\begin{tabular}{cccccc}
\hline \multirow{2}{*}{ Load Type } & & \multicolumn{2}{c}{ Residential Load } & \multicolumn{2}{c}{ Commercial Load } \\
\cline { 3 - 6 } & & $\boldsymbol{\alpha}$ & $\boldsymbol{\beta}$ & $\boldsymbol{\alpha}$ & $\boldsymbol{\beta}$ \\
\hline Summer & SDM & 0.72 & 2.96 & 1.25 & 3.5 \\
Winter & WDM & 1.04 & 4.19 & 1.5 & 3.15 \\
\hline
\end{tabular}


2.2. Modeling of DistributedEnergy Resources

\subsubsection{Fuel Cell (FC)}

The produced energy of FC is described as follows [26]:

$$
\mathrm{C}_{\mathrm{FC}}=\mathrm{C}_{\mathrm{gasFC}} \times \frac{\mathrm{P}_{\mathrm{FC}}}{\eta_{\mathrm{FC}}}
$$

2.2.2. Micro-Turbine (MT)

The output power of MT is presented as follows [26]:

$$
\mathrm{C}_{\mathrm{MT}}=\mathrm{C}_{\text {gasMT }} \times \frac{\mathrm{P}_{\mathrm{MT}}}{\eta_{\mathrm{MT}}}
$$

\subsubsection{Photovoltaic System (PVS)}

Assume the irradiance of the solar irradiance performance $\beta$ PDF and CDF are implemented to represent it according to (5) and (6) [27].

$$
\begin{aligned}
& \mathrm{f}_{\mathrm{B}}(\mathrm{si})=\left\{\begin{array}{c}
\frac{\Gamma(\alpha+\beta)}{\Gamma(\alpha) \Gamma(\beta)} \mathrm{si}^{\alpha-1} \\
0 \text { otherwise }
\end{array} \quad(1-\mathrm{si})^{\beta-1} 0 \leq \mathrm{si} \leq 1, \alpha \geq 0, \beta \geq 0\right. \\
& \mathrm{F}_{\mathrm{B}}(\mathrm{si})=\int_{0}^{\mathrm{si}} \frac{\Gamma(\alpha+\beta)}{\Gamma(\alpha) \Gamma(\beta)} \mathrm{si}^{\alpha-1}(1-\mathrm{si})^{\beta-1} \mathrm{dsi}
\end{aligned}
$$

$\alpha \& \beta$ : beta PDF parameters, that can be used as the following equation:

$$
\begin{gathered}
\alpha=\mu\left(\frac{\mu(1+\mu)}{\sigma^{2}}-1\right) \\
\beta=(1-\mu)\left(\frac{\mu(1+\mu)}{\sigma^{2}}-1\right) \\
P_{\mathrm{PV}}(\mathrm{si})=\mathrm{A}_{\mathrm{C} \cdot \eta \cdot s i}
\end{gathered}
$$

when applying Equation (5) the PDF $\mathrm{f}_{\mathrm{B}}(\mathrm{PPV})$ of the PV generated power can be obtained as the following equation:

2.2.4. Wind Turbine (WT)

$$
\mathrm{f}_{\mathrm{P}_{\mathrm{PV}}}\left(\mathrm{P}_{\mathrm{PV}}\right)=\left\{\begin{array}{ll}
\frac{\Gamma(\alpha+\beta)}{\Gamma(\alpha) \Gamma(\beta)}\left(\mathrm{A}_{\mathrm{C}} \eta \mathrm{si}\right)^{\alpha-1} \\
0 & \text { otherwise }
\end{array} \quad\left(1-\mathrm{A}_{\mathrm{C}} \eta \mathrm{si}\right)^{\beta-1} \text { ifP } \mathrm{P}_{\mathrm{PV}} \in\left[0, \mathrm{P}_{\mathrm{PV}}(\mathrm{si})\right]\right.
$$

The PDF and CDF can be expressed according to the following equations [27]:

$$
\begin{gathered}
\mathrm{F}_{\mathrm{V}}\left(\mathrm{V}_{\text {wind }}\right)=1-\exp \left(-\left(\frac{\mathrm{V}_{\text {wind }}}{\alpha_{\mathrm{w}}}\right)^{2}\right) \\
\mathrm{f}_{\mathrm{V}}\left(\mathrm{V}_{\text {wind }}\right)=\frac{2}{\alpha_{\mathrm{w}}^{2}} \mathrm{~V}_{\text {wind }} \exp \left(-\left(\frac{\mathrm{V}_{\text {wind }}}{\alpha_{\mathrm{w}}}\right)^{2}\right)
\end{gathered}
$$

when assuming the $V_{m}$ is the mean wind speed, the parameters can be obtained as the following:

$$
\mathrm{V}_{\mathrm{m}}=\alpha_{\mathrm{w}} \Gamma\left(1+\frac{1}{2}\right)=\frac{1}{2} \alpha_{\mathrm{w}} \Gamma\left(\frac{1}{2}\right)=\frac{\sqrt{\pi}}{2} \alpha_{\mathrm{w}}, \alpha_{\mathrm{w}}=\frac{2}{\sqrt{\pi}} \mathrm{V}_{\mathrm{m}}
$$


When substituting $\alpha_{\mathrm{w}}$ in PDF and CDF, the Rayleigh model for WT can be obtained as a function of average wind speed according to the Equations (12) and (13).

$$
\begin{gathered}
\mathrm{f}_{\mathrm{V}}\left(\mathrm{V}_{\text {wind }}\right)=\frac{\pi}{2} \frac{\mathrm{V}_{\text {wind }}}{\mathrm{V}_{\mathrm{m}}^{2}} \exp \left(-\left(\frac{\pi}{4}\right)\left(\frac{\mathrm{V}_{\text {wind }}}{\mathrm{V}_{\mathrm{m}}^{2}}\right)^{2}\right) \\
\mathrm{F}_{\mathrm{V}}\left(\mathrm{V}_{\text {wind }}\right)=1-\exp \left(-\left(\frac{\pi}{4}\right)\left(\frac{\mathrm{V}_{\text {wind }}}{\mathrm{V}_{\mathrm{m}}^{2}}\right)^{2}\right)
\end{gathered}
$$

The output power generated by WT is obtained in terms of wind speed $V_{\text {wind }}$ as follows:

$$
P_{\text {WT }}=\left\{\begin{array}{cc}
0 & V_{\text {wind }} \leq V_{c} \text { or } V_{\text {wind }} \geq V_{f} \\
& P_{r} \frac{V(t)-V_{c}}{V_{r}-V_{c}} V_{c} \leq V_{\text {wind }}<V_{r} \\
& P_{r} V_{r} \leq V_{\text {wind }}<V_{f}
\end{array}\right.
$$

\begin{tabular}{|c|c|c|c|c|c|c|}
\hline Generation & $\begin{array}{l}\text { Capacity } \\
\text { (kW) }\end{array}$ & $\begin{array}{l}\text { Capacity } \\
\text { Factor }\end{array}$ & $\begin{array}{l}\text { Life Time } \\
\text { (Year) }\end{array}$ & $\begin{array}{l}\text { Capital Cost } \\
(\$ / \mathbf{k W})\end{array}$ & $\begin{array}{l}\text { Maintenance } \\
\text { Cost }(\$ / k W h)\end{array}$ & $\begin{array}{c}\text { Annual } \\
\text { Conversion Factor }\end{array}$ \\
\hline FC & 400 & 0.4 & 10 & 3674 & 0.001 & 0.1006 \\
\hline MT & 250 & 1 & 10 & 750 & 0.039 & 0.2152 \\
\hline PV & 300 & 0.25 & 20 & 6675 & 0.005 & 0.0843 \\
\hline WT & 300 & 0.2 & 20 & 1500 & 0.005 & 0.1006 \\
\hline
\end{tabular}

The characteristics of different DER technologies (i.e., MT, FC, WT, and PV) are listed in Table 3.

Table 3. Characteristics of assumed distributed energy resources (DERs) technologies [28].

\subsection{Fundamental of Point Estimated Method (PEM)}

The point estimate method is a numerical method exerted to calculate the true unknown value. PEM is a stochastic technique developed by Hong which consists of $\mathrm{km}$ and $\mathrm{km}+1$ scheme (K) is a parameter depending on the type of Hong's PEM schemes. The $2 \mathrm{~m}+1$ scheme is more accurate than $2 \mathrm{~m}$ scheme due to its use the kurtosis of the input random variables. So this research work uses $2 \times \mathrm{m}+$ 1 Hong's PEM [29]. General Procedure of Point Estimate Method:

Step 1: Calculate the statistical information of the input variables.

Step 2: Calculate the concentrations for each input variable $\mathrm{x}_{1}$.

Step 3: Evaluate the $\mathrm{F}$ function at the points $\left(\mathrm{p}_{1}, \mathrm{p}_{2}, \ldots, \mathrm{x}_{1, \mathrm{k}}, \ldots, \mathrm{p}_{\mathrm{m}-1}, \mathrm{p}_{\mathrm{m}}\right)$, by theweighted probability factor. $p_{1}$ is themean value of the input variable $x_{1}$. The points $\left(p_{1}, p_{2}, \ldots, x_{1, k}, \ldots, p_{m-1}, p_{m}\right)$ includethe kth location $x_{1, k}$ and the meanvalue of $m-1$ remaining input variables $\left(\mathrm{p}_{1}, \mathrm{p}_{2}, \ldots, \mathrm{p}_{1-1}, \mathrm{p}_{1+1}, \ldots, \mathrm{p}_{\mathrm{m}-1}, \mathrm{p}_{\mathrm{m}}\right)$.

Step 4: Compute the statistical information of the output variable $(\mathrm{Z})$

$$
\mathrm{Z}(\mathrm{l}, \mathrm{k})=\mathrm{F}\left(\mathrm{p}_{1}, \mathrm{p}_{2}, \ldots, \mathrm{p}_{1}, \ldots, \mathrm{p}_{\mathrm{m}}\right)
$$

For each random variable $p_{1}$, the three locations are calculated using mean value $\left(\mu_{p, 1}\right)$ and variance value $\left(\sigma_{\mathrm{p}, 1}\right)$ of $\mathrm{p}_{1}$

$$
\mathrm{p}_{\mathrm{l}, \mathrm{k}}=\mu_{\mathrm{pl}}+\xi_{\mathrm{pl}, \mathrm{k}} \cdot \sigma_{\mathrm{pl}} \mathrm{k}=1,2,3
$$

The standard location, weighting factor $\omega_{1, k}$ of the uncertain parameters are determined by the following equation:

$$
\xi_{\mathrm{l}, \mathrm{k}}=\frac{\lambda_{\mathrm{pl}, 3}}{2}+(-1)^{3-\mathrm{k}} \sqrt{\lambda_{\mathrm{pl}, 4}+\frac{3}{4} \lambda_{\mathrm{pl}, 3}^{2}} \text { For } \mathrm{k}=1,2 \quad \xi_{\mathrm{l}, 3}=0
$$




$$
\omega_{1, k}=\frac{(-1)^{3-k}}{\xi_{1, k}\left(\xi_{1,1}-\xi_{1,2}\right)}, \omega_{1,3}=\frac{1}{m}-\frac{1}{\lambda_{1,4}-\lambda_{1,3}^{2}} \text { For } \mathrm{k}=1,2 \xi_{1,3}=0
$$

The parameters $\lambda_{\mathrm{pl}, 3}, \lambda_{\mathrm{pl}, 4}$ are the third and the fourth standard central moments of $\mathrm{p}_{1}$ which are defined as coefficients of skewness and kurtosis as follows:

$$
\lambda_{\mathrm{pl}, 3}=\frac{\mathrm{E}\left[\left(\mathrm{p}_{1}-\mu_{\mathrm{pl}}\right)^{3}\right]}{\left(\sigma_{\mathrm{pl}}\right)^{3}}, \lambda_{\mathrm{pl}, 4}=\frac{\mathrm{E}\left[\left(\mathrm{p}_{1}-\mu_{\mathrm{pl}}\right)^{4}\right]}{\left(\sigma_{\mathrm{pl}}\right)^{4}}
$$

In current work, $\left(\mathrm{K}=3, \xi_{1, \mathrm{k}}=0\right)$ is applied for wind and PV power uncertainties.After computing two pairs of locations and weights $\left(\mathrm{p}_{1, k}, \omega_{1, k}, \mathrm{k}=1,2\right)$ for each point, the output function $Z$ will be computed for each variable and for each concentrated point $Z(1, k)$ based on $F\left(\mu_{p 1}, \mu_{p 2}, \ldots, p_{1, k}, \ldots, \mu_{p m}\right)$. The jth order moment of $\mathrm{Zj}$ can be computed as follow:

$$
\mathrm{E}\left(\mathrm{Z}^{\mathrm{j}}\right) \cong \sum_{\mathrm{l}=1}^{\mathrm{m}} \sum_{\mathrm{k}=1}^{\mathrm{K}} \omega_{1, \mathrm{k}} \times\left[\mathrm{F}\left(\mu_{\mathrm{p} 1}, \mu_{\mathrm{p} 2}, \ldots, \mathrm{p}_{\mathrm{l}, \mathrm{k}}, \ldots, \mu_{\mathrm{pm}}\right)\right]^{\mathrm{j}}
$$

\section{Mathematical Problem Formulation}

\subsection{Objective Functions}

The goal of multi-objective optimal allocation of DER units is to obtain an accurate solution in the optimization process. In this article, three objective functions are examined for optimization as shown below:

\subsubsection{Power Loss (Technical Benefit):}

Reducing the total system power loss is mainly affected by the optimal allocation of the DERs problem. The power loss equation can be defined as follows [30].

$$
\mathrm{F}_{1}(\mathrm{x})=\mathrm{P}_{\mathrm{L}}(\mathrm{x})=\left.\sum_{\mathrm{i}=1}^{\mathrm{n}_{\mathrm{br}}} \mathrm{R}_{\mathrm{i}} \mathrm{I}_{\mathrm{i}}\right|^{2}
$$

\subsubsection{Total Annual Energy Cost (Annual Economic Benefit)}

After installing DERs in the network, the overall real losses $\left(\mathrm{P}_{\mathrm{L}}^{\mathrm{wDER}}\right)$ is decreased when compared to that without DER $\left(\mathrm{P}_{\mathrm{L}}^{\mathrm{WODER}}\right)$. The cost provided by DERs is given in [31]. Annual cost has been calculated as the difference in energy loss cost without DER and with DER. The DER cost includes the cost of DER and its installation. So the total annual cost is given by the following equation [32].

$$
\begin{aligned}
& \mathrm{F}_{2}(\mathrm{x})=\left(\mathrm{C}_{\mathrm{e}} \times\left(\mathrm{P}_{\mathrm{L}}^{\mathrm{woDER}}-\mathrm{P}_{\mathrm{L}}^{\mathrm{wDER}}\right)+\mathrm{C}_{\mathrm{DER}}\right) \times 8760 \\
& C_{D E R}=\sum_{i=1}^{N_{F C}} C_{F C_{i}}+\sum_{i=1}^{N_{W T}} C_{W T_{i}}+\sum_{i=1}^{N_{G a s}} C_{G a s_{i}}+\sum_{i=1}^{N_{P V}} C_{P V_{i}}
\end{aligned}
$$

\subsubsection{Total Greenhouse Gas Emission (Environmental Benefit)}

The third objective function $\left(\mathrm{F}_{3}\right)$ is considered to minimize the harmful gas emission into the environment resulted from the substation and DER units. The values of emission coefficients of DER units and the grid are given in [31].

$$
F_{3}(x)=\sum_{i=1}^{N_{M T}} E_{M T_{i}}+\sum_{i=1}^{N_{F C}} E_{F C_{i}}+\sum_{i=1}^{N_{P V}} E_{P V_{i}}+\sum_{i=1}^{N_{W T}} E_{W T_{i}}+E_{\text {grid }}
$$




\subsection{Constraints}

\subsubsection{Equality Constraints}

The basics of equilibrium effect on the equality constraints. Real and interactive power balance equations can be written as below [32]:

$$
\begin{aligned}
& P_{i}=V_{i} \sum_{j=1}^{n_{\text {bus }}} V_{j} Y_{i j} \cos \left(\theta_{i j}-\delta_{i}+\delta_{j}\right) \\
& Q_{i}=V_{i} \sum_{j=1}^{n_{\text {bus }}} V_{j} Y_{i j} \sin \left(\theta_{i j}-\delta_{i}+\delta_{j}\right)
\end{aligned}
$$

The real and complex power that can be injected when the energy sources are taking into account for distribution system can be calculated as the following equations

$$
\begin{gathered}
P_{i}=P_{g i}-P_{d i} \\
Q_{i}=Q_{g i}-Q_{d i}
\end{gathered}
$$

\subsubsection{Inequality Constraints}

- Bus Voltage constraints

The bus voltages amplitude at the radial network should be limited by prescribed operating conditions, which appear as the following equation:

$$
\mathrm{V}_{\mathrm{i}}^{\min } \leq \mathrm{V}_{\mathrm{i}} \leq \mathrm{V}_{\mathrm{i}}^{\max }
$$

where, $\mathrm{V}_{\mathrm{i}}^{\min }=0.95$ and $\mathrm{V}_{\mathrm{i}}^{\max }=1.05$

- Power generation limit

It contains the limits of the maximum real power of the DERs and assuring that the whole DERs capable to work within the permissible limits as the following equation:

$$
\mathrm{P}_{\text {gi }} \leq \mathrm{P}_{\text {gi }}^{\text {limit }}
$$

\section{Preliminaries of Proposed Algorithm}

\subsection{Review of WaterCycle Algorithm}

The water cycle optimization algorithm (WCA) mimics the stream of rivers and flow directly to the sea and derived by the notification of the water cycle process [33]. The complete details are used from [32]. The general procedures of the multi-objective water cycle algorithm (MOWCA) are summarized as follows [32].

Step 1: Choose the initial parameters for the MOWCA: $\mathrm{N}_{\mathrm{sr}}, \mathrm{dmax}, \mathrm{N}_{\mathrm{pop}}$, Max Iteration, and Pareto archive size.

Step 2: Generate a random initial population and form the initial streams, rivers, and sea by using equations as below.

$$
\text { Total population }=\left[\begin{array}{c}
\text { Sea River1, River2, River3 } \\
\text { StreamNsr }+1, \text { StreamNsr }+2, \text { StreamNsr }+3 \\
\text { StreamNpop }
\end{array}\right]
$$




$$
\begin{aligned}
& \mathrm{N}_{\mathrm{sr}}=\text { Numbers of River }+1 \text { (sea) } \\
& \mathrm{N}_{\text {Stream }}=\mathrm{N}_{\mathrm{POP}}-\mathrm{N}_{\mathrm{Sr}}
\end{aligned}
$$

Step 3: Calculate the value of multi-objective functions for each stream using Equation (36).

$$
C_{i}=\operatorname{Cost}_{i}=f\left(x_{1}^{i}, x_{2}^{i}, \ldots, x_{3}^{i}\right)
$$

Step 4: Determine the non-dominated solutions in the initial population and save them in the Pareto archive.

Step 5: Determine the non-dominated solutions among the feasible solutions and save them in the Pareto archive

Step 6: Calculate the crowding-distance for each Pareto archive member.

Step 7: Select a sea and rivers based on the crowding-distance value.

Step 8: Determine the intensity of the flow for rivers and sea-based on the crowding distance values using Equation (37).

$$
\mathrm{NS}_{\mathrm{n}}=\operatorname{round}\left\{\left|\frac{\text { Cost }_{\mathrm{n}}}{\sum_{\mathrm{i}}^{\mathrm{N}_{\mathrm{Sr}} \text { Cost }_{\mathrm{i}}}}\right| \times \mathrm{N}_{\text {Stream }}\right\} \mathrm{n}=1,2, \ldots, \mathrm{NSr}
$$

Step 9: Streams flow into the rivers using Equation (38).

$$
\mathrm{X}_{\text {Stream }}^{\mathrm{i}+1}=\mathrm{X}_{\text {Stream }}^{\mathrm{i}}+\operatorname{rand} \times \mathrm{C} \times\left(\mathrm{X}_{\text {River }}^{\mathrm{i}}-\mathrm{X}_{\text {Stream }}^{\mathrm{i}}\right)
$$

Step 10: Exchange positions of the river with a stream which gives the best solution.

Step 11: Some streams may directly flow into the sea using Equation (39).

$$
X_{\text {Stream }}^{\mathrm{i}+1}=X_{\text {Stream }}^{\mathrm{i}}+\operatorname{rand} \times \mathrm{C} \times\left(X_{\text {Sea }}^{\mathrm{i}}-X_{\text {Stream }}^{\mathrm{i}}\right)
$$

Step 12: Exchange positions of the sea with a stream which gives the best solution.

Step 13: Rivers flow into the sea using Equation (40).

$$
X_{\text {River }}^{\mathrm{i}+1}=X_{\text {River }}^{\mathrm{i}}+\operatorname{rand} \times \mathrm{C} \times\left(X_{\text {Sea }}^{\mathrm{i}}-X_{\text {River }}^{\mathrm{i}}\right)
$$

Step 14: Exchange positions of the sea with a river which gives the best solution.

Step 15: Check the evaporation condition.

Step 16: If the evaporation condition is satisfied, the raining process will occur using Equation (41).

$$
\mathrm{X}_{\mathrm{Stream}}^{\mathrm{New}}=\mathrm{LB}+\operatorname{rand} \times(\mathrm{UB}-\mathrm{LB})
$$

Step 17: Reduce the value of $d_{\max }$ which is a user-defined parameter using Equation (42).

$$
\mathrm{d}_{\max }^{\mathrm{i}+1}=\mathrm{d}_{\max }^{\mathrm{i}}-\frac{\mathrm{d}_{\max }^{\mathrm{i}}}{\text { maxIteration }}
$$

Step 18: Determine the new feasible solutions in the population.

Step 19: Determine the new non-dominated solutions among the feasible solutions and save them in the Pareto archive.

Step 20: Eliminate any dominated solutions in the Pareto archive.

Step 21: If the number of members in the Pareto archive is more than the determined Pareto archive size, go to Step 22, otherwise, go to Step 23. 
Step 22: Calculate the crowding-distance value for each Pareto archive member and remove as many members as necessary with the lowest crowding-distance value.

Step 23: Calculate the crowding-distance value for each Pareto archive member to select new sea and rivers.

Step 24: Check the convergence criteria. If the stopping criterion is satisfied, the algorithm will be stopped, otherwise return to Step 9.

\subsection{Non-Dominated Sorting Genetic Algorithm (NSGA-III)}

A modified version of NSGA, called NSGA-II, developed by Deb et al. (2000) and Deb et al. (2002), utilizes a fast non-dominated sorting genetic algorithm. This method is computationally efficient, non-elitism preventing, and less dependent on a sharing parameter for diversity preservation. Recently, a reference-point based multi-objective NSGA-II algorithm (called NSGA-III) is proposed by Deb and Jain, which is more efficient to solve problems with more than two objectives [33]. The main procedure of NSGA-III can be briefly described below. NSGA-III starts with the definition of a set of reference points. Then an initial population with $\mathrm{N}$ members is randomly generated, where $\mathrm{N}$ is the population size. The next steps are iterated until the termination criterion is satisfied. At the $t$-th generation, the current parent population $\mathrm{Pt}$ is used to produce an offspring population $\mathrm{Q}_{t}$ by using random selection, simulated binary crossover (SBX) operator and polynomial mutation. The size of $\mathrm{Pt}$ and $Q t$ are both $N$. subsequently, the two populations $P_{t}$ and $Q_{t}$ are merged together to form a new population $R_{t}=P_{t} \cup Q_{t}$ (of size $2 N$ ). To choose the best $N$ members from $R_{t}$ for the next generation, the non-dominated sorting based on the usual domination principle $[34,35]$ is first used, which classifies $\mathrm{R}_{\mathrm{t}}$ into different non-domination levels $\left(\mathrm{F}_{1}, \mathrm{~F}_{2}\right.$, and so on). Then, a new population $\mathrm{S}_{\mathrm{t}}$ is constructed by filling members of different non-domination levels one at a time, starting from $\mathrm{F}_{1}$, until the size of $\mathrm{St}$ equals to $\mathrm{N}$ or for the first time becomes greater than $\mathrm{N}$. Let us suppose that the last level included is the l-th level. Hence, the solutions from the level $1+1$ onwards are simply rejected. Members in $S_{t} \backslash F_{1}$ are already chosen for $P_{t+1}$, and the remaining population slots are chosen from $F_{1}$ such that the desired diversity is maintained in the population. In the original NSGA-II, the solutions in $\mathrm{F}_{1}$ with the largest crowding distance values are selected. However, the crowding distance measure does not perform well for many-objective problems. Thus, the selection mechanism in NSGA-III is modified by conducting a more systematic analysis of members in $S_{t}$ with respect to the supplied reference points. To achieve this, objective values and supplied reference points are first normalized so that they have an identical range. After normalization, the ideal point of the set $S_{t}$ is the zero vectors. Thereafter, the perpendicular distance between a member in St and each of the reference lines (joining the ideal point with a reference point) is calculated. Each member in $S_{t}$ is then associated with a reference point having the minimum perpendicular distance. Next, the niche count $\rho j$ for the j-th reference point, defined as the number of members in $S_{t} \backslash F_{1}$ that are associated with the $j$-th reference point, can be obtained based on the above process. Further, a niche-preservation operation is executed to select members from Fl, and it works as follows. First, the reference point set $\mathrm{J}_{\min }=\left\{\mathrm{j}: \operatorname{argmin}_{\mathrm{j}} \rho_{\mathrm{j}}\right\}$ having the minimum $\rho_{\mathrm{j}}$ value is identified. In case of $\left|J_{\min }\right|>1$, one $-\mathrm{j} \in \mathrm{J}_{\min }$ is randomly chosen. If $\rho_{\mathrm{j}}^{-}=0$, we choose the one having the shortest perpendicular distance to the $j$-th reference line among members associated with the $j$-th reference point in $\mathrm{F}_{1}$ and add it to $\mathrm{P}_{\mathrm{t}+1}$. The count of $\rho_{\mathrm{j}}^{-}$is then increased by one. In the event $\rho_{\mathrm{j}} \geq 1$, a randomly chosen member from front $F l$ that is associated with the $j$-th reference point is added to $P_{t+1}$, and the count of $\rho_{\mathrm{j}}^{-}$also needs increasing by one. In both of the two cases, once there exists no such member to be selected, the $j$-th reference point is excluded from further consideration for the current generation. After niche counts are updated, the above niche operation is repeated for a total of $K=N$ $-\left|S_{t} \backslash F_{l}\right|$ times to fill the remaining population slots of $P_{t+1}$. For more details of NSGA-III, please refer to [33].The pseudo-codes of NSGA-III are shown in Figure 1. 


\section{Non-dominated sorting genetic algorithm (NSGA-III ) procedure}

Input: $\mathrm{H}$ processed reference points Zs or predefined desired points

Za, parent population $\mathrm{Pt}$

Output: Pt+1

$\mathrm{St}=\phi, \mathrm{i}=1$

$\mathrm{Qt}=$ Recombination + Mutation $(\mathrm{Pt})$

$\mathrm{R}_{\mathrm{t}}=\mathrm{P}_{\mathrm{t}} \cup \mathrm{Q}_{\mathrm{t}}$

$(\mathrm{F} 1, \mathrm{~F} 2, \ldots)=$ Non-dominated-sort $(\mathrm{Rt})$

repeat

$\mathrm{St}=\mathrm{St} \cup \mathrm{Fi}$ and $\mathrm{i}=\mathrm{i}+1$

until $\mid$ St $\mid \geq N$

Last front to be included: $\mathrm{Fl}=\mathrm{Fi}$

if $|S t|=N$ then

$\mathrm{Pt}+1=$ St, break

else

$\mathrm{Pt}+1=\cup i-1 \mathrm{j}=1 \mathrm{Fj}$

Points to be selected from F $1: \mathrm{K}=\mathrm{N}-|\mathrm{Pt}+1|$

Normalize objectives and generate reference set $\mathrm{Zr}$ :

Normalize(fn, St, Zr , Zs, Za)

Associate each individual s of St with a reference point: $[\pi(s)$,

$\mathrm{d}(\mathrm{s})]=$ Associate $($ St, $\mathrm{Zr})$

$\% \pi(\mathrm{s})$ : closest reference point, $\mathrm{d}$ : distance between $\mathrm{s}$ and $\pi(\mathrm{s})$

Calculate niche count of reference point $\mathrm{j} \in \mathrm{Zr}: \mathrm{ej}=\sum S \in S F \mathrm{t} \quad((\pi)(\mathrm{s}=\mathrm{j}) / 1: 0)$

Select $\mathrm{K}$ individuals one at a time from $\mathrm{Fl}$ to generate

$\mathrm{P}_{\mathrm{t}+1}$ : Niching $(\mathrm{K}, \mathrm{ej}, \pi, \mathrm{d}, \mathrm{Zr}, \mathrm{Fl}, \mathrm{Pt}+1)$

end if

Figure 1. Non-dominated sorting genetic algorithm (NSGA-III).

\subsection{Best Compromise Solution}

The power system operators may have imprecise goals for the DERs planning problem. Therefore, a fuzzy-based mechanism is employed over the tradeoff curve of the Pareto optimal set obtained by the MOWCA and NSGA-III algorithm to extract the best compromise solution. The value of the membership function $\mu_{i}^{\mathrm{k}}$ is calculated for the kth solution of the ith objective function, as follows [34]:

$$
\mu_{i}^{k}=\left\{\begin{array}{lr}
1 & \text { for } F_{i}(x) \leq F_{i}^{\min } \\
F_{i}^{\text {Max }}-f_{i}(x) & \text { for } F_{i}^{M i n} \leq f_{i}(x) \leq F_{i}^{\operatorname{Max}} \\
F_{i}^{\text {Max }}-F_{i}^{\text {Min }} & \text { for } F_{i}(x) \geq F_{i}^{\max } \\
0 &
\end{array}\right.
$$


For each non-dominated solution in the archive set, the normalized membership function $\mathrm{U}^{\mathrm{k}}$ is calculated as follows:

$$
\mathrm{U}^{\mathrm{k}}=\frac{\sum_{\mathrm{i}=1}^{\mathrm{N}_{\mathrm{obj}}} \mu_{\mathrm{i}}^{\mathrm{k}}}{\sum_{\mathrm{k}=1}^{\mathrm{N}_{\text {Archive }}} \sum_{\mathrm{i}=1}^{\mathrm{N}_{\mathrm{obj}}} \mu_{\mathrm{i}}^{\mathrm{k}}}
$$

The solution that has the maximum value of $\mathrm{U}^{\mathrm{k}}$ is considered the best compromise solution. In this paper, all objective functions have the same importance (weight factor).

The values of input data parameters used in NSGA-III and MOWCA are summarized in Table 4.

Table 4. Values of parameter settings used in non-dominated sorting genetic algorithm (NSGA-III) and multi-objective water cycle algorithm (MOWCA).

\begin{tabular}{lclc}
\hline \multicolumn{1}{c}{ Parameter } & NSGA-III & \multicolumn{1}{c}{ Parameter } & MOWCA \\
\hline Population size N & 80 & Population size & 80 \\
Evaluation generation & 50 & Evaluation generation & 50 \\
Crossover probability $\left(\mathrm{p}_{\mathrm{c}}\right)$ & 0.5 & $\mathrm{~N}_{\mathrm{sr}}$ (Number of rivers + sea) & 4 \\
Mutation probability $\left(\mathrm{p}_{\mathrm{m}}\right)$ & 0.5 & $\mathrm{~d}_{\max }$ (Maximum allowable & $1 \times 10^{-16}$ \\
Distribution index for a crossover $(\eta \mathrm{c})$ & 30 & & \\
Distribution index for mutation $\left(\eta_{\mathrm{m}}\right)$ & 20 & & \\
\hline
\end{tabular}

\section{Results and Discussion}

To define the impact of the suggested algorithm carried out on a test system of IEEE-33 bus systems and the IEEE-69 bus network. The cost of the energy losses per $\mathrm{kWh}$ is supposed to be $\$ 0.05$ [31]. The planning of hybrid power system model added to different load models, like constant, residential and commercial load models at summer day load (SDM) and winter day load (WDM) are made by employing MOWCA and NSGA-III form minimization of total power loss, total annual energy cost, and emission while placing the DERs in appropriate locations. The simulations have been carried out over six different cases as shown in Table 5.

Table 5. The case studies presented in this study.

\begin{tabular}{|c|c|c|c|}
\hline Case Study & \multicolumn{2}{|c|}{ Load Models } & System \\
\hline Case 1 & \multicolumn{2}{|c|}{ Constant load } & \multirow{3}{*}{ IEEE- 33 bus system } \\
\hline Case 2 & $\begin{array}{l}\text { Residential load } \\
\text { Commercial load }\end{array}$ & At summer day & \\
\hline Case 3 & $\begin{array}{l}\text { Residential load } \\
\text { Commercial load }\end{array}$ & At winter day & \\
\hline Case4 & \multicolumn{2}{|c|}{ Constant load } & \multirow{3}{*}{ IEEE-69 bus system } \\
\hline Case5 & $\begin{array}{l}\text { Residential load } \\
\text { Commercial load }\end{array}$ & At summer day & \\
\hline Case 6 & $\begin{array}{l}\text { Residential load } \\
\text { Commercial load }\end{array}$ & At winter day & \\
\hline
\end{tabular}

\subsection{IEEE 33- Bus System}

For examining the feasibility of the suggested MOWCA optimization technique, a test system consists of 33-bus and 32 branches are used. $100 \mathrm{MVA}$, and $12.66 \mathrm{kV}$ operating parameters, and loading parameters are $3720 \mathrm{~kW}$ and $2300 \mathrm{kVAr}$ respectively. The active and reactive losses without installing DER units are $202.7 \mathrm{~kW}$ and $140.03 \mathrm{kVAr}$, respectively. The system parameters are found in [31].

\subsubsection{Case 1: Constant Load Model}

The results calculated by the suggested MOWCA algorithm are shown in Table 4. It is compared to the results obtained by other techniques like NSGA-III for comparative study with the suggested 
algorithm. It is observed from Table 6 that a significant reduction is achieved by MOWCA in the annual energy cost $(683,595.915$ \$) and Emission $(5489.94691 \mathrm{Ib} / \mathrm{h})$ in comparison with NSGA-III while the power loss achieved by MOWCA method (103.9202 kW) is higher than NSGA-III method. Figure 2 shows a set of non-dominated solutions or Pareto optimal fronts of constant load model.

Table 6. Simulation results using MOWCA and NSGA-III for optimization of power loss, annual economic loss and emission under different loads such as the Summer Day Load Model (SDM) and Winter Day Load Model (WDM) (IEEE-33 bus systems).

\begin{tabular}{|c|c|c|c|c|c|c|c|c|c|c|c|}
\hline \multirow{3}{*}{ Method } & \multirow{3}{*}{$\begin{array}{c}\text { Type of } \\
\text { DG }\end{array}$} & \multirow{2}{*}{\multicolumn{2}{|c|}{ Constant }} & \multicolumn{4}{|c|}{ Summer Day Load Model (SDM) } & \multicolumn{4}{|c|}{ Winter Day Load Model (WDM) } \\
\hline & & & & \multicolumn{2}{|c|}{ Residential Load } & \multicolumn{2}{|c|}{ Commercial Load } & \multicolumn{2}{|c|}{ Residential Load } & \multicolumn{2}{|c|}{ Commercial Load } \\
\hline & & $\begin{array}{l}\text { Location } \\
\text { (bus no) }\end{array}$ & $\begin{array}{l}\text { Size } \\
(\mathrm{kW})\end{array}$ & $\begin{array}{l}\text { Location } \\
\text { (bus no) }\end{array}$ & $\begin{array}{l}\text { Size } \\
(\mathrm{kW})\end{array}$ & $\begin{array}{l}\text { Location } \\
\text { (bus no) }\end{array}$ & $\begin{array}{l}\text { Size } \\
(\mathrm{kW})\end{array}$ & $\begin{array}{l}\text { Location } \\
\text { (bus no) }\end{array}$ & $\begin{array}{l}\text { Size } \\
(\mathrm{kW})\end{array}$ & $\begin{array}{l}\text { Location } \\
\text { (bus no) }\end{array}$ & $\begin{array}{l}\text { Size } \\
(\mathrm{kW})\end{array}$ \\
\hline \multirow{9}{*}{$\begin{array}{l}\text { MOWCA } \\
\text { method }\end{array}$} & \multirow{3}{*}{ MT } & (27) & 89.751 & (13) & 135.25 & (9) & 250 & (6) & 198.37 & $(32)$ & 241.53 \\
\hline & & (13) & 73.116 & \multirow{2}{*}{$\begin{array}{l}(26) \\
(27)\end{array}$} & 150 & (5) & 172.95 & (9) & 121.99 & (27) & 116.8 \\
\hline & & (13) & 0 & & 129.85 & (24) & 100 & (19) & 153.42 & (27) & 0 \\
\hline & & (29) & 210.71 & (27) & 0 & (18) & 400 & $(24)$ & .82 & $(20)$ & 200 \\
\hline & & (18) & & $(21)$ & & $(30)$ & & (15) & & (13) & \\
\hline & PV & (14) & - & (28) & - & (8) & - & (10) & & (8) & - \\
\hline & & (26) & & (14) & & (28) & & (22) & & (30) & \\
\hline & & (16) & & (24) & & (32) & & (14) & & (17) & \\
\hline & WT & (28) & - & (29) & - & (6) & - & (26) & & (23) & - \\
\hline & F1 (kW) & 103.92 & & 71.25 & & 54.955 & 523 & 69.683 & & & \\
\hline & F2 (\$) & 683.595 & & 710.536 & & $793,960.7$ & 79887 & 738.466 & & 835 & .76 \\
\hline & F3 (Ib/h) & 5489.94 & & 5105.50 & & 4779.93 & 3565 & 4928.27 & & 462 & 045 \\
\hline & & (31) & 58.58 & (27) & 61 & (21) & 0.23526 & (33) & & (17) & 19.834 \\
\hline & MT & (32) & 247 & (5) & 053 & (17) & 0.021001 & (28) & & (11) & 242.84 \\
\hline & & (23) & 134.5 & (9) & .97 & (2) & 0.032842 & (11) & .99 & (18) & 133.4 \\
\hline & & (7) & & (14) & .51 & (17) & 0 & (21) & 9.5 & (11) & 0 \\
\hline NSGA-III & FC & (7) & 17.24 & (18) & 28 & (33) & 0.33302 & (15) & & (12) & 229.63 \\
\hline method & & (25) & 0343.6 & (14) & 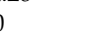 & (15) & 0.12261 & (9) & & (23) & 251.36 \\
\hline & & (4) & & (22) & & (18) & & (25) & & (3) & \\
\hline & PV & (15) & - & (16) & . & (14) & - & (26) & & (27) & - \\
\hline & & (12) & & (30) & & (19) & & (31) & & (31) & \\
\hline & & (12) & & (12) & & (4) & & (31) & & (21) & \\
\hline & WT & (28) & - & (2) & . & (30) & - & (6) & & (24) & - \\
\hline & & (17) & & (32) & & (25) & & (28) & & (14) & \\
\hline & $F_{1}(k W)$ & 96.547 & & 77.651 & & 70.532 & 227 & 53.64945 & & & \\
\hline & $\mathrm{F}_{2}(\$)$ & 744204 & & 757584.5 & 805 & 739478.4 & 40639 & 818483.861 & & 792 & 977 \\
\hline & $\mathrm{F}_{3}(\mathrm{Ib} / \mathrm{h})$ & 5520.95 & & 5078.22 & & 4964.23 & 3913 & 5087.94170 & & 479 & 071 \\
\hline
\end{tabular}

* The best solution marked in bold.
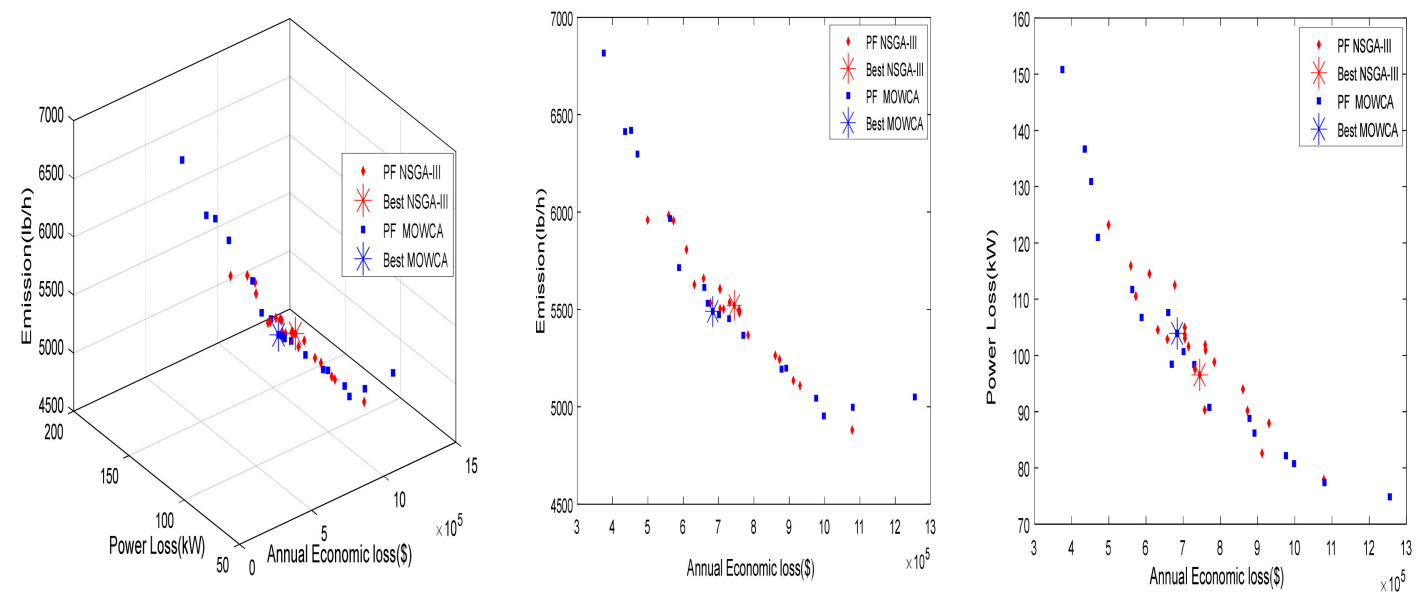

Figure 2. Distribution of Pareto-optimal solution for the constant load model in the IEEE 33 bus system. 


\subsubsection{Case 2: Summer Day Load Model (SDM)}

- Residential load

Table 6 depicts the multi-objective output for the residential load model. The network losses are $164 \mathrm{~kW}$ before the installation of any DER, and after installing they are reduced to $71.2596 \mathrm{~kW}$.From Table 4 it is clear that the MOWCA method significantly improves the system performance in terms of reduction of the power loss of $(71.2596 \mathrm{~kW})$ and annual energy cost $(710,536.85 \$)$ as compared with NSGA-III. However, the emission $(5078.22182 \mathrm{lb} / \mathrm{h})$ is less in NSGA-III.

- Commercial load

Table 6 illustrates the obtained results from implementing multi-objective optimization for the commercial load model. Before installing any DER the system losses are $152 \mathrm{~kW}$ and after installing they are reduced to $54.95 \mathrm{~kW}$. The simulation results show that the MOWCA method reduces power losses and emissions. However, the annual energy cost is less in NSGA-III. Figure 3 shows Pareto optimal fronts and three dimensional residential and commercial load models at summer day load model.
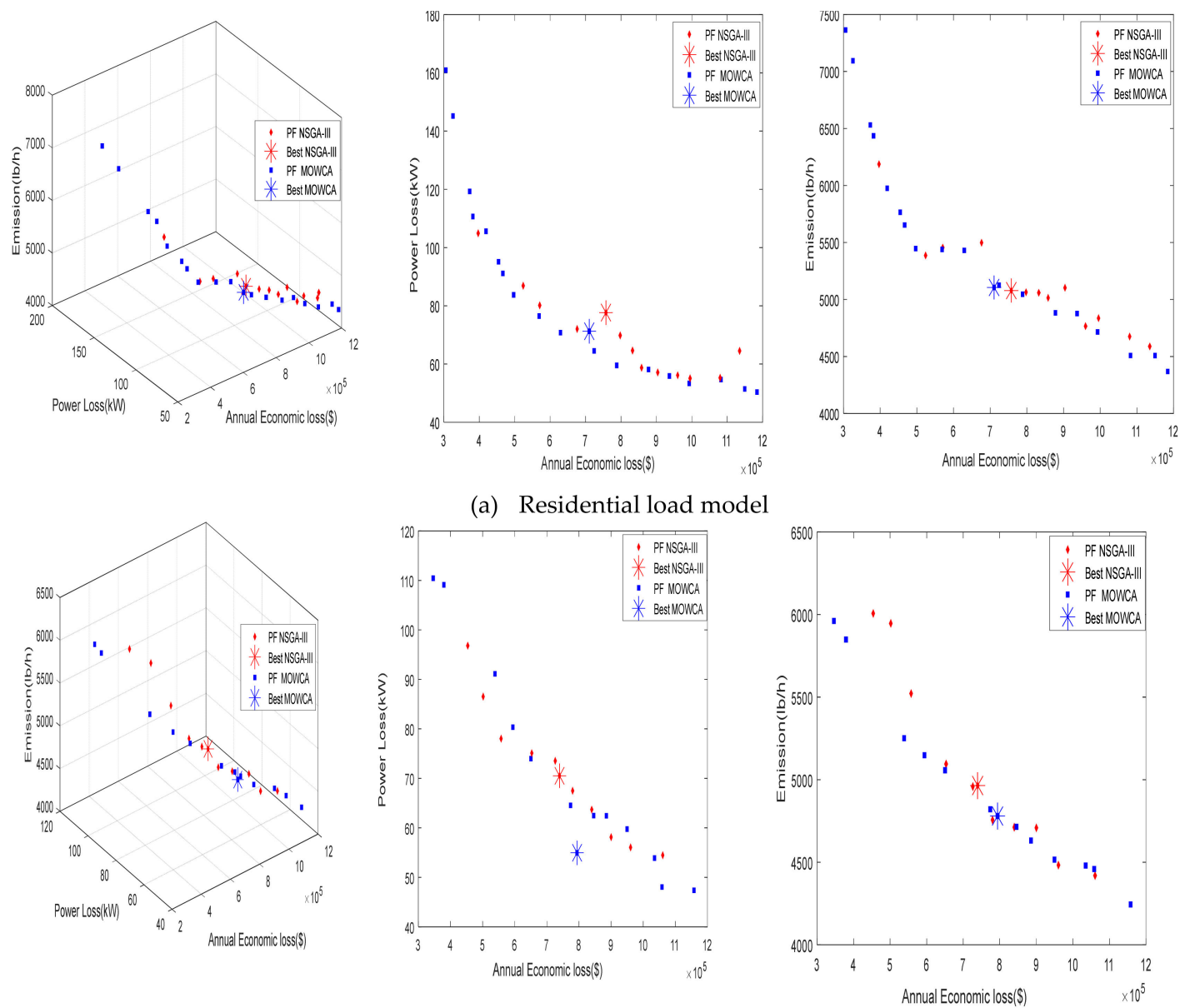

(b) Commercial load model

Figure 3. Distribution of Pareto-optimal solutions for residential and commercial load models at summer day load in the IEEE 33 bus system.

\subsubsection{Case 3: Winter Day Load Model (WDM)}

\section{- Residential load}

The output results using MOWCA optimization algorithms are compared to the NSGA-III method and summarized in Table 6 . The comparison proves that the suggested MOWCA provides the most 
reduction is achieved in annual cost and emission as compared with NSGA-III method. While the power loss achieved by MOWCA $(69.68398 \mathrm{~kW})$ is higher than NSGA-III $(53.64945 \mathrm{~kW})$.

- Commercial load

The output results deduced using the suggested MOWCA are compared to NSGA-III as presented in Table 6. It may be notified that MOWCA significantly reduces the power loss and emission as compared with the NSGA-III algorithm. However, the annual cost is less in NSGA-III. Figure 4 shows Pareto optimal fronts and three dimensional residential and commercial load models at the winter day load model.
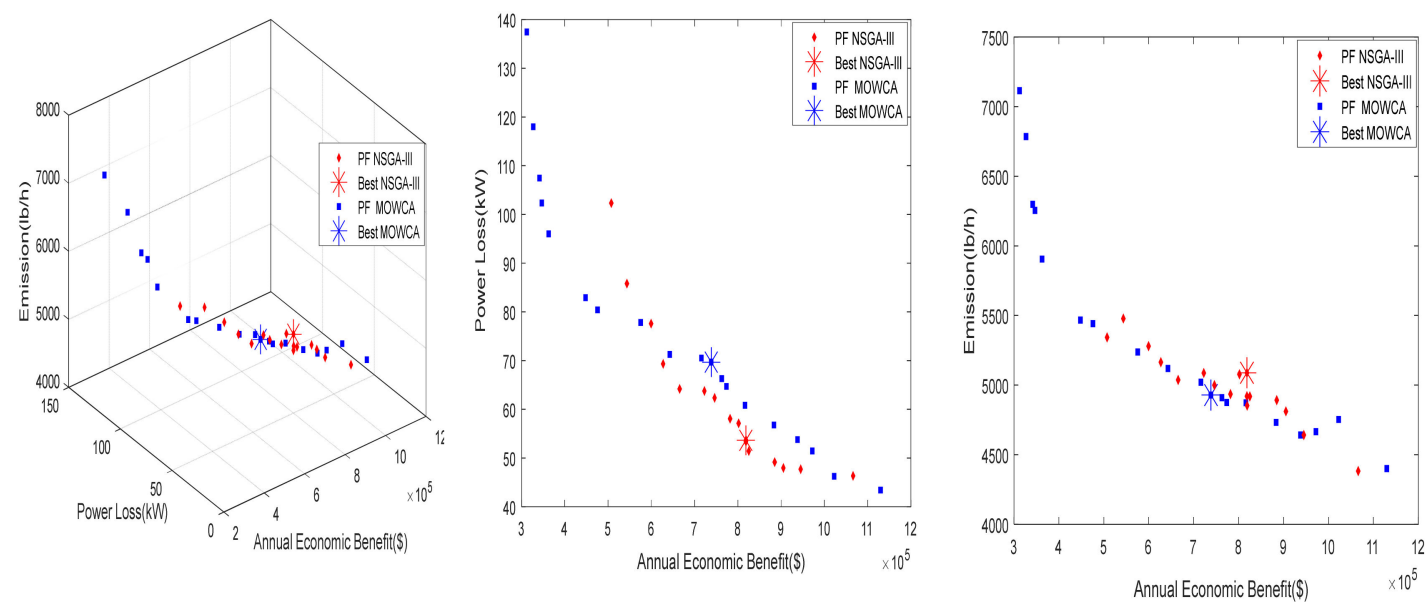

(a) Residential load model
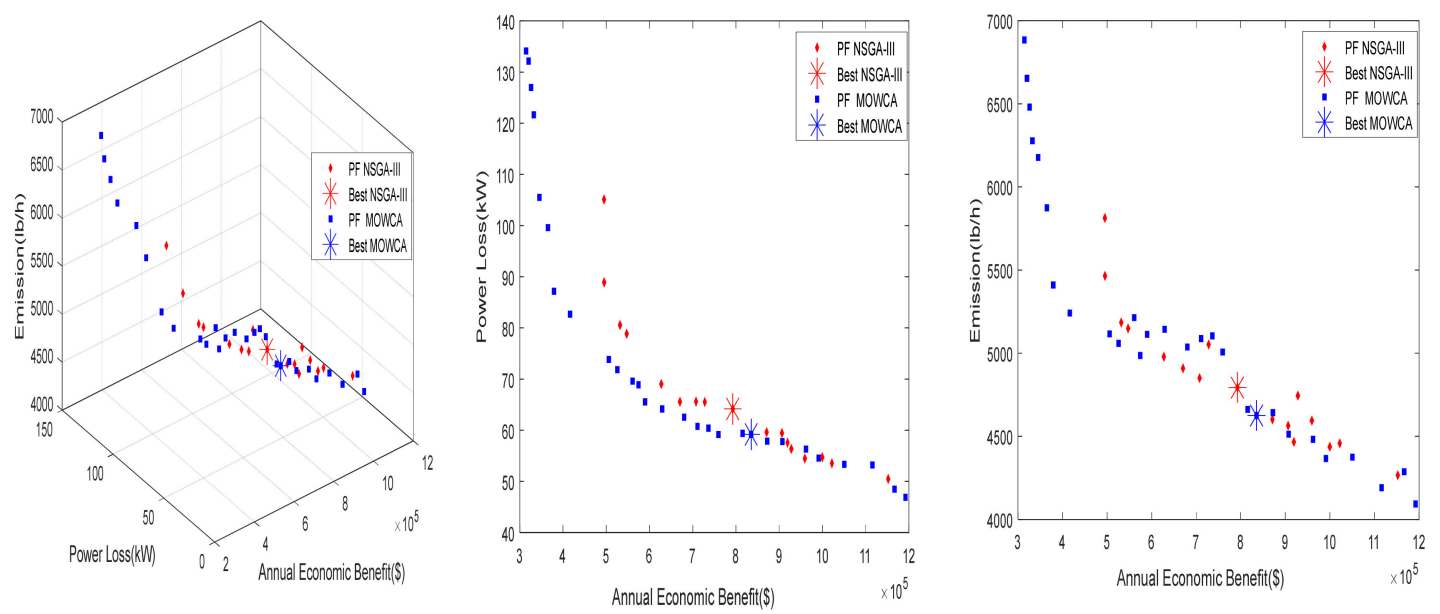

(b) Commercial load model

Figure 4. Distribution of Pareto-optimal solutions for residential and commercial load models at winter day load in the IEEE 33 bus system.

\subsection{IEEE 69- Bus System}

To show the performance of the proposed optimization techniques on a huge network is developed using a 69-bus network, the second test system used is 69-bus systems with a load of $3800 \mathrm{~kW}$ and 2690 $\mathrm{kVAr}$, respectively and the data related to this test system was taken from [31]. Before the placement of DG units, the total active and reactive power losses are $224.95 \mathrm{~kW}$ and $102.12 \mathrm{kVAr}$, respectively. 


\subsubsection{Case 4: Constant Load Model}

From Table 7, it is clearly notified that the results obtained by MOWCA show that significant reduction is achieved in the active power losses $(135.852 \mathrm{~kW})$ and annual energy cost $(653,778.637 \$)$ in comparison with NSGA-III while the emission achieved by MOWCA method (5622.082 Ib/h) is higher than NSGA-III method. A group of non-dominated solutions or Pareto optimal fronts of constant load model are shown in Figure 5.

Table 7. Simulation results using MOWCA and NSGA-III for optimization of power loss, annual economic loss and emission under different loads such as SDM and WDM (IEEE-69 bus systems).

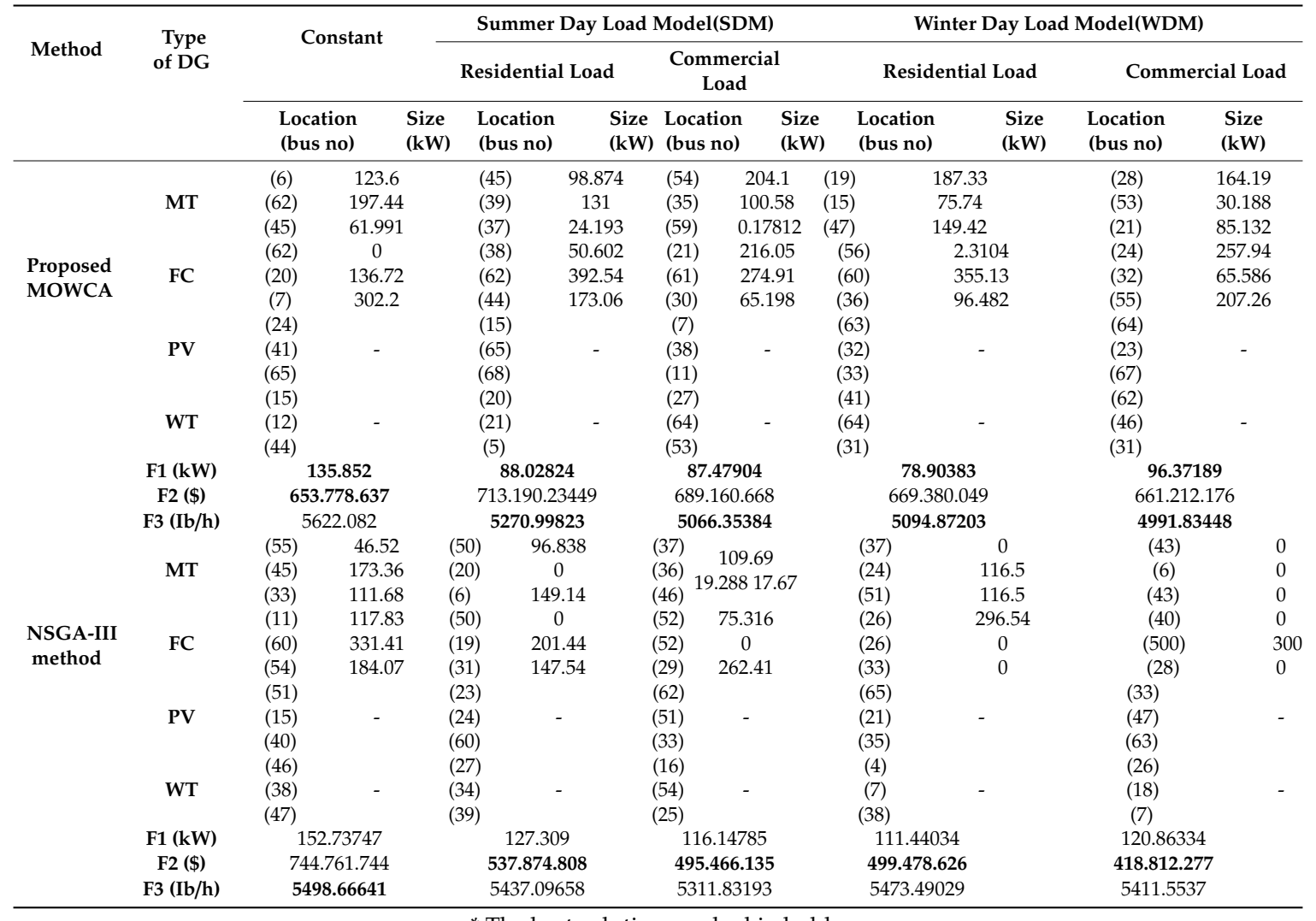

* The best solution marked in bold.
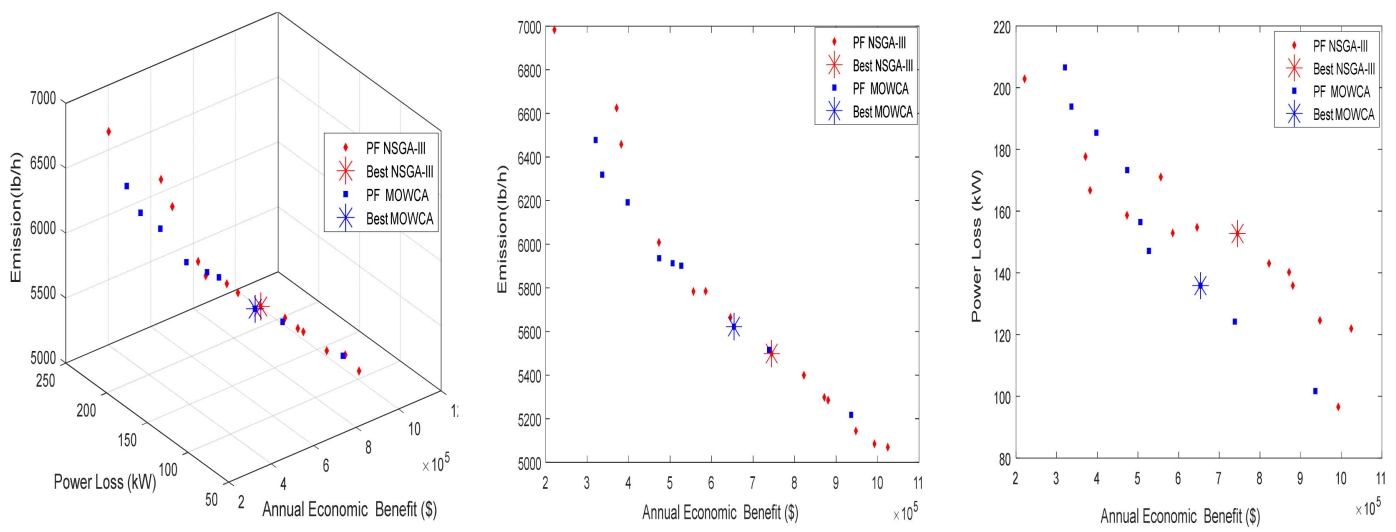

Figure 5. Distribution of Pareto-optimal solution for the constant load model in the IEEE 69 bus system.

\subsubsection{Case 5: Summer Day Load (SDM)}

- Residential load 
Before installing any DER the system losses are $177 \mathrm{~kW}$ active power loss and after installing they are reduced to $88.02824 \mathrm{~kW}$. Form Table 7, it can be noticed that the results obtained by MOWCA show that significant reduction is achieved in power loss $(88.02824 \mathrm{~kW})$ and emission $(5270.99823 \mathrm{Ib} / \mathrm{h})$ as compared with the NSGA-III while the annual economic benefit achieved by MOWCA(713,190.234\$) is higher than NSGA-III $(537,874.808 \$)$.

\section{- Commercial load}

Before installing any DER, the system losses are $162 \mathrm{~kW}$ active power loss and after installing they are reduced to $97.75 \mathrm{~kW}$. Form Table 7, it can be seen that the MOWCA method significantly improve the system performance in terms of reduction of power loss of $(87.47904 \mathrm{~kW})$ and emission (5066.35384 $\mathrm{Ib} / \mathrm{h}$ ) as compared with NSGA-III. However, the annual economic benefit is less in NSGA-III method. Figure 6 shows Pareto optimal fronts and three dimensional of residential and commercial load model at summer day load.
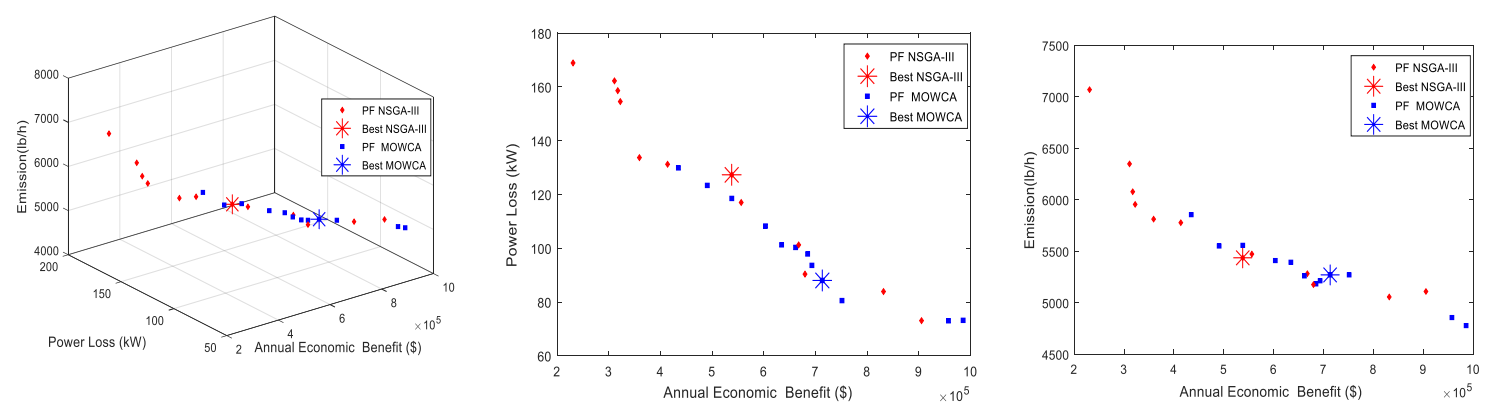

(a) Residential load model
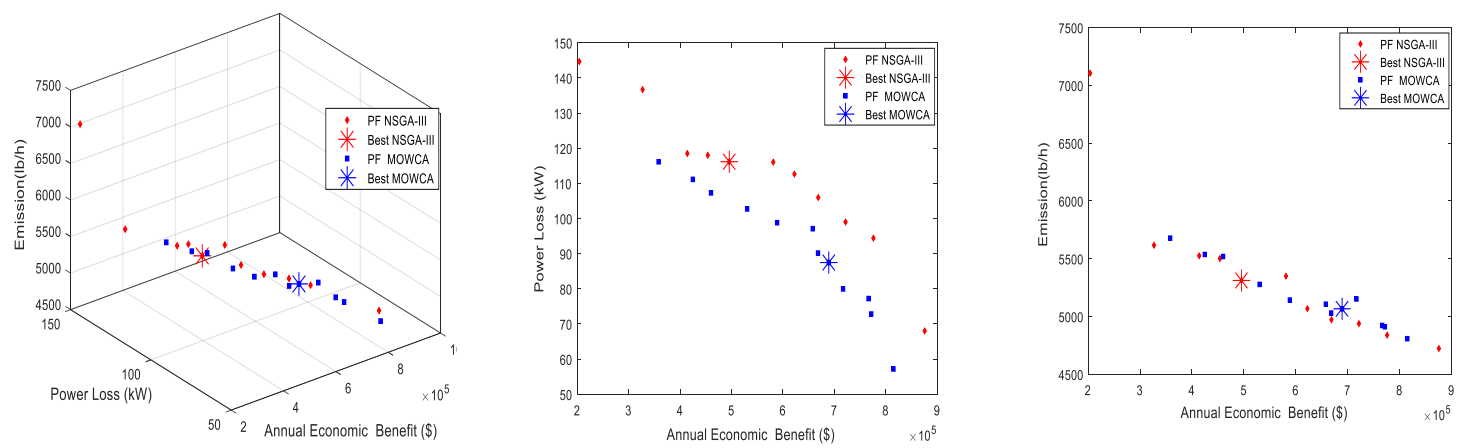

(b) Commercial load model

Figure 6. Distribution of Pareto-optimal solutions for residential and commercial load models at summer day load in the IEEE-69 bus system.

\subsubsection{Case 6: Winter Day Load Model (WDM)}

- Residential load

Without allocation DER, the network losses are $161 \mathrm{~kW}$ and after installing they are reduced to $78.90383 \mathrm{~kW}$. The simulation results show that the MOWCA method reduces power losses and emission in an effective manner. However, the total annual energy cost is high compared with the method NSGA-III.

- Commercial load

Without installing DER, the network losses are $159 \mathrm{~kW}$ and after installing they are reduced to $(96.37189 \mathrm{~kW})$. It may further be noted from Table 7 that the power losses and emission obtained by the MOWCA method which provides highly accurate results in compared with that obtained by NSGA-III method while the annual energy cost achieved by NSGA-III is lower than MOWCA method. Figure 7 
shows Pareto optimal fronts and three dimensional residential and commercial load models at winter day load.
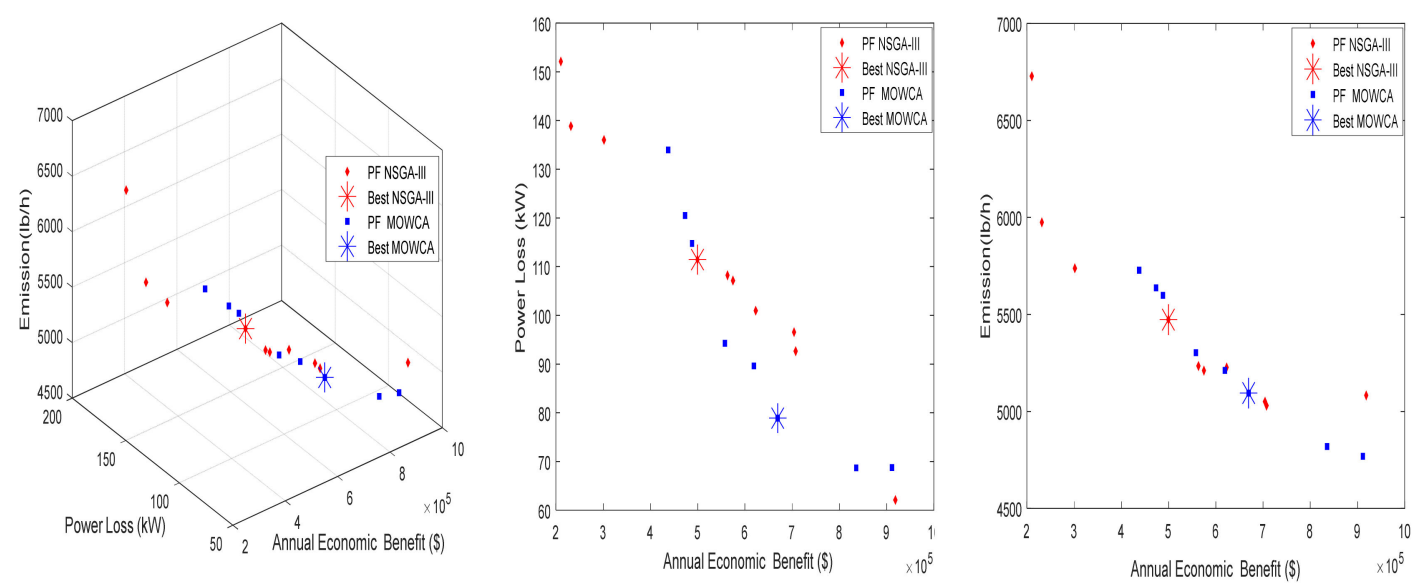

(a) Residential load model
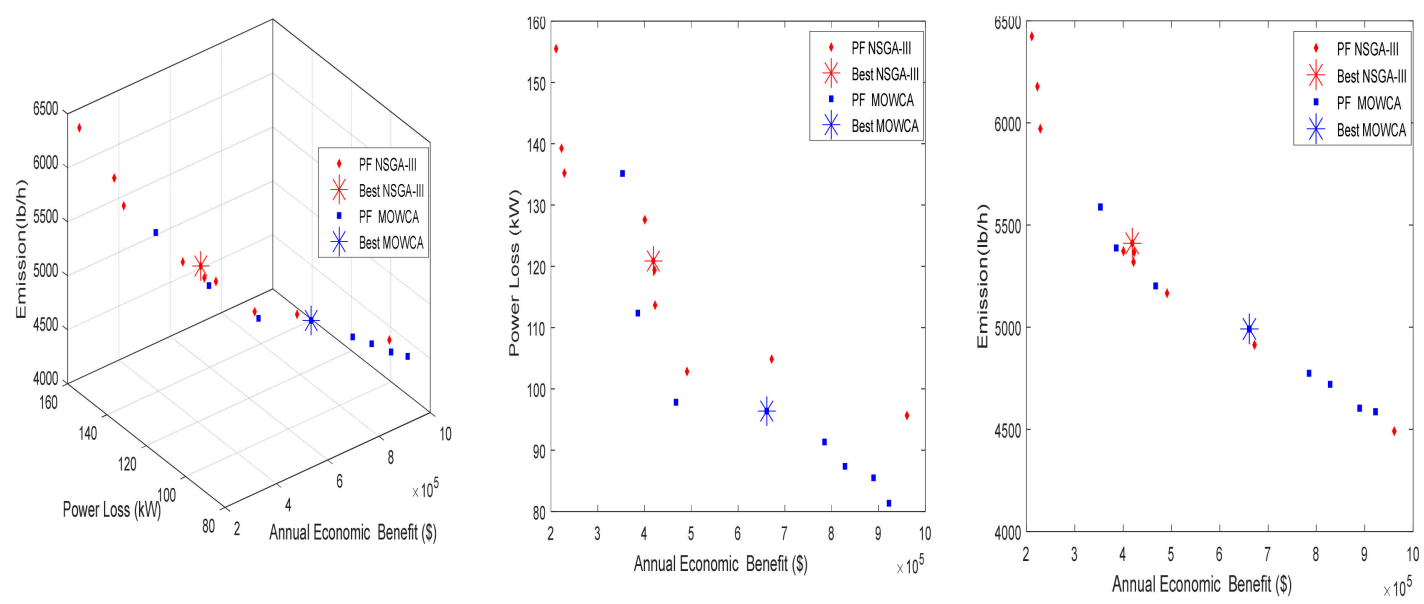

(b) Commercial load model

Figure 7. Distribution of Pareto-optimal solutions for residential and commercial load models at winter day load in the IEEE-69 bus system.

\section{Conclusions}

In this article, the Multi-objective Water Cycle Algorithm (MOWCA) is proposed to determine the optimum placement and size of a hybrid power system model consisting of various combinations of a conventional system and renewable energy resources. Various optimization problems are addressed in this article such as real power loss, annual energy cost, and greenhouse gas emission as objective functions. The prime aim of considering these objectives is minimization of power loss, annual energy cost, and greenhouse gas emission. The DER planning with MOWCA method is tested for different voltage-dependent load models, namely constant, residential, and commercial load at summer and winter day load models in IEEE 33 bus and 69 bus distribution systems. The attained results by MOWCA method are compared with NSGA-II algorithm to validate its performance. It is clear from the comparison of simulation results that MOWCA was capable of obtaining better solutions than NSGA-III approach for multi-objective problems. The results indicated that enhancement of the distribution power system performance parameters depends on the size of DERs and their suitable placement in the distribution power systems. It was clear the proposed MOWCA method proves that the economic and environmental benefit is achieved with the optimal allocation of DERs at the 
constant load and residential load in the winter day load model regarding to other load models for IEEE 33-bus system while technical and economic benefit is got at the constant load with respect to other load models for the IEEE 69-bus system. The technical and environmental benefit is obtained at commercial load in summer and winter day load model for the IEEE 33-bus system and also at residential load for the IEEE 69-bus system while the technical and e economic benefit is attained at residential load in summer day load model for IEEE 33-bus system.

Author Contributions: Conceptualization, A.-A.A.M., A.M.H., and S.M. (Shimaa Ali); methodology, A.-A.A.M., and S.A. (Salem Alkhalaf); software, S.A. (Salem Alkhalaf) and T.S.; validation, T.S.; formal analysis, T.S., and A.M.H..; investigation, S.A. (Shimaa Ali); resources, S.A. (Shimaa Ali); data curation, A.-A.A.M.; writing-original draft preparation, S.A. (Shimaa Ali); writing-review and editing, A.M.H.; visualization, T.S.; supervision, A.M.H., and T.S.; project administration, A.-A.A.M.

Funding: This research received no external funding.

Acknowledgments: The authors would like to thank the reviewer committee for their valuable comments, which help the authors to raise the article quality.

Conflicts of Interest: The authors declare no conflict of interest with any other researchers.

\section{Nomenclature}

$\begin{array}{llll}\mathrm{C}_{\mathrm{FC}} & \text { Fuel consumption cost of a fuel cell }(\$ / \mathrm{h}) & \mathrm{P}_{\mathrm{Sub}} & \text { Substation active power } \\ \mathrm{C}_{\mathrm{gasF}} & \text { Price of natural gas supplied to fuel cell } & \mathrm{P}_{\mathrm{gi}}^{\max } & \text { Real power limit of the ith generator } \\ \mathrm{C}_{\mathrm{MT}} & \text { Fuel consumption cost of micro-turbine }(\$ / \mathrm{h}) & \mathrm{P}_{\mathrm{FC}} & \text { Output power of fuel cell } \\ \mathrm{C}_{\mathrm{gasMT}} & \text { Natural gas price supplied to micro-turbine } & \mathrm{P}_{\mathrm{MT}} & \text { Output power of micro-turbine } \\ \mathrm{F}_{\mathrm{i}} & \text { The ith objective function } & \mathrm{P}_{\mathrm{WT}} & \text { Wind turbine output power } \\ \eta_{\mathrm{FC}} & \text { Fuel cell efficiency } & \mathrm{P}_{\mathrm{r}} & \text { Rated/nominal power of the wind turbine } \\ \eta_{\mathrm{MT}} & \text { Micro-turbine efficiency } & \mathrm{P}_{\mathrm{Sub}} & \text { Substation active power } \\ \mathrm{I}_{\mathrm{i}} & \text { The current of ith branch } & \xi 1, \mathrm{k} & \text { Standard location of kth point } \\ \mathrm{G}_{\mathrm{r}} & \text { Annual conversion factor } & \mu \mathrm{pl} & \text { Mean deviation of pl random input variable } \\ \mathrm{LF} & \text { The load factor } & \mathrm{Q}_{\mathrm{di}} & \text { Load demand reactive power at ith bus } \\ \mathrm{n}_{\mathrm{br}} & \text { Number of branches } & \mathrm{R}_{\mathrm{i}} & \text { Resistance of ith branch } \\ \mathrm{n} & \text { Nominal output power of photovoltaic panel } & \mathrm{sn} & \text { Nominal illumination intensity of the photovoltaic } \\ \mathrm{N}_{\mathrm{MT}} N_{M T} & \text { Numbers of the micro-turbine } & \mathrm{V}_{\mathrm{c}} & \text { Wind cut-in speed } \\ N_{F C} & \text { Numbers of the fuel cell } & \mathrm{V}_{\mathrm{f}} & \text { Wind cut-out speed } \\ N_{P V} & \text { Numbers of the Photovoltaic } & \mathrm{V}_{\mathrm{r}} & \text { Wind rated speed } \\ N_{W T} & \text { Numbers of the wind turbine } & \mathrm{V} & \text { Actual speed of the wind turbine } \\ \mathrm{Ploss} & \text { Total system active power losses } & \mathrm{V}_{\mathrm{i}}^{\max } & \text { Upper voltage limits of ith bus } \\ P_{M T_{i}} & \text { Real output power of the ith micro-turbine } & \mathrm{V}_{\mathrm{i}}^{\min } & \text { Lower voltage limits of ith bus } \\ P_{P V_{i}} & \text { Real output power of the ith Photovoltaic } & & \\ P_{W T_{i}} & \text { Real output power of the ith wind turbine } & & \\ \mathrm{P}_{\mathrm{gi}} & \text { Active powers of the ith energy source } & & \end{array}$

\section{References}

1. Sawle, Y.; Gupta, S.C.; Bohre, A.K. Review of hybrid renewable energy systems with comparative analysis of off-grid hybrid system. Renew. Sustain. Energy Rev. 2018, 81, 2217-2235. [CrossRef]

2. Zhang, W.; Maleki, A.; Rosen, M.A.; Liu, J. Optimization with a simulated annealing algorithm of a hybrid system for renewable energy including battery and hydrogen storage. Energy 2018, 163, 191-207. [CrossRef]

3. Diemuodeke, E.O.; Addo, A.; Oko, C.O.C.; Mulugetta, Y.; Ojapah, M.M. Optimal mapping of hybrid renewable energy systems for locations using multi-criteria decision-making algorithm. Renew. Energy 2019, 134, 461-477. [CrossRef]

4. Guo, S.; Liu, Q.; Sun, J.; Jin, H. A review on the utilization of hybrid renewable energy. Renew. Sustain. Energy Rev. 2018, 91, 1121-1147. [CrossRef]

5. Buch, H.; Trivedi, I.N. A new non-dominated sorting ions motion algorithm: Development and applications. Decis. Sci. Lett. 2019, 9, 59-76. [CrossRef]

6. Mirjalili, S.; Jangir, P.; Saremi, S. Multi-objective ant lion optimizer: A multi-objective optimization algorithm for solving engineering problems. Appl. Intell. 2017, 46, 79-95. [CrossRef] 
7. Tawhid, M.A.; Savsani, V. Multi-objective sine-cosine algorithm (MO-SCA) for multi-objective engineering design problems. Neural Comput. Appl. 2019, 31, 915-929. [CrossRef]

8. Bhadoria, V.S.; Pal, N.S.; Shrivastava, V. Artificial immune system based approach for size and location optimization of distributed generation in distribution system. Int. J. Syst. Assur. Eng. Manag. 2019, 10, 339-349. [CrossRef]

9. Mobin, M.; Mousavi, S.M.; Komaki, M.; Tavana, M. A hybrid desirability function approach for tuning parameters in evolutionary optimization algorithms. Measurement 2018, 114, 417-427. [CrossRef]

10. Veeramani, C.; Sharanya, S. Analyzing the Performance Measures of Multi-Objective Water Cycle Algorithm for Multi-Objective Linear Fractional Programming Problem. In Proceedings of the 2018 Second International Conference on Intelligent Computing and Control Systems (ICICCS), Madurai, India, 14-15 June 2018; pp. 297-306.

11. Devabalaji, K.R.; Ravi, K. Optimal size and sitting of multiple DG and DSTATCOM in radial distribution system using Bacterial Foraging Optimization Algorithm. Ain Shams Eng. J. 2016, 7, 959-971. [CrossRef]

12. Melgar-Dominguez, O.D.; Pourakbari-Kasmaei, M.; Lehtonen, M.; Mantovani, J.R. Voltage-Dependent Load Model-Based Short-Term Distribution Network Planning Considering Carbon Tax Surplus. IET Gener. Transm. Distrib. 2019, 13, 3760-3770. [CrossRef]

13. Chauhan, A.; Saini, R.P. Discrete harmony search based size optimization of integrated renewable energy system for remote rural areas of Uttarakhand state in India. Renew. Energy 2016, 94, 587-604. [CrossRef]

14. Halabi, L.M.; Mekhilef, S.; Olatomiwa, L.; Hazelton, J. Performance analysis of hybrid PV/diesel/battery system using HOMER: A case study Sabah, Malaysia. EnergyConvers. Manag. 2017, 144, 322-339. [CrossRef]

15. Guangqian, D.; Bekhrad, K.; Azarikhah, P.; Maleki, A. A hybrid algorithm based optimization on modeling of grid independent biodiesel-based hybrid solar/wind systems. Renew. Energy 2018, 122, 551-560. [CrossRef]

16. Peng, W.; Maleki, A.; Rosen, M.A.; Azarikhah, P. Optimization of a hybrid system for solar-wind-based water desalination by reverse osmosis: Comparison of approaches. Desalination 2018, 442, 16-31. [CrossRef]

17. Singh, S.S.; Fernandez, E. Modeling, size optimization and sensitivity analysis of a remote hybrid renewable energy system. Energy 2018, 143, 719-731. [CrossRef]

18. Ikeda, S.; Takeda, A.; Ohmori, H. Optimal sizing of photovoltaic systems for loss minimization in distribution network. In Proceedings of the 2018 SICE International Symposium on Control Systems (SICE ISCS), Tokyo, Japan, 9-11 March 2018; pp. 185-192.

19. Nadjemi, O.; Nacer, T.; Hamidat, A.; Salhi, H. Optimal hybrid PV/wind energy system sizing: Application of cuckoo search algorithm for Algerian dairy farms. Renew. Sustain. Energy Rev. 2017, 70, 1352-1365. [CrossRef]

20. Samy, M.M.; Barakat, S.; Ramadan, H.S. A flower pollination optimization algorithm for an off-grid PV-Fuel cell hybrid renewable system. Int. J. Hydrog. Energy 2019, 44, 2141-2152. [CrossRef]

21. Duong, M.Q.; Pham, T.D.; Nguyen, T.T.; Doan, A.T.; Tran, H.V. Determination of Optimal Location and Sizing of Solar Photovoltaic Distribution Generation Units in Radial Distribution Systems. Energies 2019, 12, 174. [CrossRef]

22. Yahiaoui, A.; Benmansour, K.; Tadjine, M. Control, analysis and optimization of hybrid PV-Diesel-Battery systems for isolated rural city in Algeria. Sol. Energy 2016, 137, 1-10. [CrossRef]

23. Li, Y.; Feng, B.; Li, G.; Qi, J.; Zhao, D.; Mu, Y. Optimal distributed generation planning in active distribution networks considering integration of energy storage. Appl. Energy 2018, 210, 1073-1081. [CrossRef]

24. Asmi, R.Y.; Salama, M.; Ahmad, I.A. Distributed generation's integration planning involving growth load models by means of genetic algorithm. Arch. Electr. Energy 2018, 67, 667-682.

25. Singh, B.; Mukherjee, V.; Tiwari, P. GA-based multi-objective optimization for distributed generations planning with DLMs in distribution power systems. J. Electr. Syst. Inf. Technol. 2017, 4, 62-94. [CrossRef]

26. Moradi, M.H.; Eskandari, M.; Hosseinian, S.M. Operational strategy optimization in an optimal sized smart micro grid. IEEE Trans. Smart Grid 2015, 6, 1087-1095. [CrossRef]

27. Aghajani, G.R.; Shayanfar, H.A.; Shayeghi, H. Demand side management in a smart micro-grid in the presence of renewable generation and demand response. Energy 2017, 126, 622-637. [CrossRef]

28. Esmaeili, M.; Sedighizadeh, M.; Esmaili, M. Multi-objective optimal reconfiguration and DG (Distributed Generation) power allocation in distribution networks using Big Bang-Big Crunch algorithm considering load uncertainty. Energy 2016, 103, 86-99. 
29. Aien, M.; Hajebrahimi, A.; Fotuhi-Firuzabad, M. A comprehensive review on uncertainty modeling techniques in power system studies. Renew. Sustain. Energy Rev. 2016, 57, 1077-1089. [CrossRef]

30. Imran, M.; Kowsalya, M. Optimal size and siting of multiple distribution generators in distribution system using bacterial foraging optimization. Swarm Evol. Comput. 2014, 15, 58-65. [CrossRef]

31. Kefayat, M.; Ara, A.L.; Niaki, S.N. A hybrid of ant colony optimization and artificial bee colony algorithm for probabilistic optimal placement and sizing of distributed energy resources. Energy Convers. Manag. 2015, 92, 149-161. [CrossRef]

32. Rao, B.H.; Sivanagaraju, S. Optimum allocation and sizing of distributed generations based on clonal selection algorithm for loss reduction and technical benefit of energy savings. In Proceedings of the 2012 International Conference on Advances in Power Conversion and Energy Technologies (APCET), Mylavaram, Andhra Pradesh, India, 2-4 August 2012; pp. 1-5.

33. Sadollah, A.; Eskandar, H.; Kim, J.H. Water cycle algorithm for solving constrained multi-objective optimization problems. Appl. Soft Comput. 2015, 27, 279-298. [CrossRef]

34. Deb, K.; Jain, H. An evolutionary many-objective optimization algorithm using reference-point-based non-dominated sorting approach, part I: Solving problems with boxconstraints. IEEE Trans. Evol. Comput. 2014, 18, 577-601. [CrossRef]

35. Hashim, H.A.; Abido, M.A. Location management in lte networks using multi-objective particle swarm optimization. Comput. Netw. 2019, 157, 78-88. [CrossRef]

(C) 2019 by the authors. Licensee MDPI, Basel, Switzerland. This article is an open access article distributed under the terms and conditions of the Creative Commons Attribution (CC BY) license (http://creativecommons.org/licenses/by/4.0/). 